\title{
Potassium Titanyl Phosphate (KTP) レーザーの脳神経外科手術への使用経験 Neurosurgical application of potassium titanyl phosphate (KTP) laser
}

\author{
临藤 洋一, 加藤 天美, 種子田 護, 吉峰 俊樹, \\ 有田 憲生, 池田 卓也*, 早川 徹 \\ 大阪大学医学部脳神経外科 \\ 于565 大阪府吹田市山田丘 2-2 \\ *大阪大学医学部中央手術部
}

\begin{abstract}
Youichi SAITOH, Amami KATO, Mamoru TANEDA, Toshiki YOSHIMINE, Norio ARITA, Takuya IKEDA* and Toru HAYAKAWA

The Department of Neurosurgery, Osaka University Medical School *Surgical Center, Osaka University Medical School
\end{abstract}

\begin{abstract}
要 旨
KTP (Potassium titanyl phosphate) レーザー手術装置を種々の開頭術の際に使用し，そ の有用性を検討した。本装置はNd：YAGレーザー光を $\mathrm{K} \mathrm{T} P$ 結晶により周波数を递倍し，緑 色レーザー光として出力する。この波長はへモグロビンの吸収極大とほぼ一致し，止血的切開能 力の向上が図られている。レーザー光は直径0.3mm的 $0.6 \mathrm{~mm}$ の水晶ファイバーにより術野に導か れる。小型軽量のバヨネット型ハンドピースは操作性に優狆て抢り，街野の妨げとなることはな かった。また出力部先端が焼損しても容易に更新できた。これらの特性により従来摘出困難上さ れていた脳や頭蓋底梁部の腫痬性病変でも，確実に蒸散，凝固が可能であり，極めて有用であっ た。種々の照射条件による深達度を組織学的に検討した結果，KTPレーザーによる熱変性は照 射部位に比較的限局することが動物実験でも臨床例でも明らかとなり，本装置を傎重に使用すれ ば，術野周辺への影響を最小にして，支全に手術が可能となることが確かめられた。
\end{abstract} キーワード：KTPレーザー，YAGレーザー，脳神経外科手術テクニック

\section{Abstract}

We have used potassium titanyl phosphate (KTiOPO4: KTP) laser in various craniotomies, and evaluated its efficacy. The KTP laser has a wavelength of $532 \mathrm{~nm}$, which is just a half wavelength of neodymium:yttrium-alminum-garnet (Nd: Y AG) laser. Its

(平成 5 年 4 月28日受理, 平成 5 年 6 月 21 日揭載決定)

(Received April 28th 1993, Accepted June 21 th 1993) 
energy is easily absorbed in hemoglobin because the wavelength is very close to that of maximum absorption to hemoglobin. This evidence is beneficial for the hemostatic cutting. The KTP laser light is delivered through a flexible quartz fiber to the operative field. The visible green laser light allows the surgeon to set the target precisely. With the light bayonet hand piece, the laser could be introduced even through a minimun opening to the deep seated skull base tumors. The laser was used in both contact and non-contact methods with simply cleaving the tip of the fiber, whenever polluted. The tissue damage caused by laser irradiation was investigated with brain tumors as well as rat cereberum. It was disclosed that the thickness of thermal damage was no more than $1.5 \mathrm{~mm}$ when the laser mode was set for the usual tumor evacuation. These features of the KTP laser apparatus in considered to be powerful advantage for using in microneurosurgery.

Key words : Potassium Titanyl Phosphate(KTP)laser, Nd:YAG laser, Neurosurgical technique.

\section{【はじめに】}

脳腫瘍外科領域へのレーザーの応用は，1966年にruby レーザーを用いたのが最初である゙。1970年代より C O 2 レーザーが脳神経外科領域に尊入され2.3.4.5), さらに 1980年Beckら ${ }^{6}$ がNd：YAGレーザーを導入し，CO2 レーザーとともに併用されるようになっだ。両者の特 徵を簡単にまとめると，CO2レーザーは限局した部位 を無血的に蒸散でき，硬くて出血性の腫湟にも有効であ る ${ }^{8)}$ 。Nd：YAGレーザーは組織透過性が高く，散乱 して厚い熱凝固層をつくるため, 止血性が高いが、蒸散 能力が低いという欠点がある8”。ところでこれらのレー ザ一は特殊な症例を除き，一般的な脳神経外科手術法と しては普及に至らなかっだ.10.11.12)。その理由とし て価格が非常に高く，装置が大がかりであったり，操作 性などの問題点があげられる。

最近 KTP／532レーザーが開発され，これまでに外科， 産婦人科，耳鼻科領域に導入されたがい，最近脳神経外 科領域にも活用さ机つつあるい。このレーザーはNd： YAGレーザー光(波長：1046nm)をKTP結晶により周 波数を聥倍し, 緑色レーザー光（波長： $532 \mathrm{~nm}$ ) とし て出力する。この波長はへモグロビンの吸収極大（575， $540.415 \mathrm{~nm})$ のうち540nmとほぼ一致し，止血機能の 向上が図られている。今回開頭術におけるKTP $/ 532$ レーザー手術装置の特徴および有用性について報告する。

\section{【方 法】}

\section{〈KTPレーザー手術装置〉}

本体は小型化 $(\mathrm{W}: 51.4, \mathrm{D}: 90.2, \mathrm{H}: 130.8 \mathrm{~cm})$
が図られており，本体の移動，設定が容易で，騒音も小 さかった。冷却水之排水用パイプの接続が必要である。 光ファイバーは直径 $0.3 ， 0.4 ， 0.6 \mathrm{~mm}$ のから選ぶこと ができ，術野や病変によって，また切開，蒸散，凝固の それぞれの目的に沁じて，そのまま接触法，非接触法の どちらにも使用できる。様々な長さのバイヨネット型の ハンドピースと組み合わ女ると，深部の病変でも術野を 妨げることなく確実に蒸散減圧や凝固が可能であった。 ハンドピースは小型軽量で長時間使用しても街者に疲労 はなかった。光ファイバーはテフロンでコーティングさ 机ており，レーザー出力部は先端のテフロンを除去して 使用する。術中先端が焼損す执ば，先端を切断し，テフ ロンコーティングを除去することで更新できる。この作 業は簡単で 1 分以内に施行できた。照準光と手術光は同 一波長の緑色可視光で同一光路を通るため，焦点にずれ が発生せず，高い手術精度が得られた。フィルターモ ジュールは手術用顕微鏡に装着され、レーザー使用時の みフィルターが作動, 従来の眼鏡型フィルターに比べ顕 微鏡下レーザー手術が容易になっている。

〈対 象〉

15例の脳神経外科手術にKTPレーザー手術装置 (LASERSCOPE，CA，USA) を使用した。内訳は 噵膜腫が 5 例, くも膜噍胞が 2 例, 脊索腫, 下垂体腺腫, モヤモヤ病，星細胞腫，筃神経芽腫，血管腫，聴神経鞘 腫, AVMが各々1例である。㗙膜腫, 青索腫, 星細胞 腫, 嗅神経芽腫, 血管腫, 聴神経鞘腫では腫韵切除に使 用し，特に㗙膜腫では腫瘍硬膜付着部の焼灼に用いた。 経蝶形洞下垂体腺腫摘出時には, 蝶形洞粘膜焼灼, 及び 
止血に用いた。モヤモヤ病では浅側頭動脈の娳離に使用

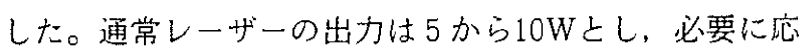
じて15Wとした。蒸散にはファイバー先端を組織に接触 あるいはごく近接させ，1秒間に $5 \mathrm{~mm}$ 程度の速度で移動 させた。凝固には組織とファイバー先端との距離を約 3 mmに保ち、1 秒間に $1 \mathrm{~cm}$ 程度の速度で対象領域を走査す るように動かした。

\section{〈レーザー深達度の組織学的検討〉}

2 例の喵道膜腫および１例の星細胞腫では,レーザー照 射部位の熱变性を組織学的に検討した。すなわち直径 0.6

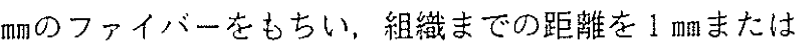
$3 \mathrm{~mm}$ として 5 または10Wで照射した。ファイバー先端の 移動速度は $1 \mathrm{~cm} /$ 秒とした。また組織表面より1または $3 \mathrm{~mm}$ の位置にファイバー先端を固定し，10Wでそれぞれ 1 秒，の秒，ならびに12秒照射した。

同様に体重300gのオスWistarラットを用いレーザー 照射による組織損傷の検討を行った。ラットはケタラー 儿麻酔下で開頭し，手術亡同様に種々の条件で大脳表面 にレーザー照射を行っだ。過量の麻酔薬注入により屠殺 し、脳はホルマリン固定の上，パラフィン切片を作成し HE染色を行った。

\section{【結 果】 \\ 〈手術応用〉}

㖪膜腫，星細胞腫では出力 5 - 10Wでファイバー先端 を $5 \mathrm{~mm} /$ 秒程度のゆっくりした速度で動かすことで，は とんよ゙出血なしに腫曒蒸散を行うことができた。より出 血性の組織にはレーザー出力を增すことで対応し，血管 腫では腫演はほぼ無血的に蒸散されていった。しかし嚊 神経芽腫例では，凝固が完了する前に血液が湧き出し， 止血が图難な場合があった。その際には，従来の才キシ セル・ビオボンドやバイポーラー凝固錙子で止血した。 一般には出血さえコントロールでき机ば腫瘍の蒸散減圧 は確実に行うことができた。特に斜台霄菜腫例では超音 波破砕吸引装置が入らない頭蓋底深部の弾性硬腫瘍の蔐 出にきわめて有用であった。くも膜娂胞切除にも用いた が，くも膜下腔と交通をつけることは可能であった。そ の他浅側頭動脈の㧳離や経蝶形洞手術における粘膜の止 血にも有用性が認められた。しかしAVM剥離操作にお いては動静脈吻合のため赤色を呈する血管の止血は困難 であった。また表面が白色の, 特に石灰化病変の摘出に はレーザー光の吸収が覀いためか，蒸散に時間を要した。 ガイド光が可視であるため, 非接触法で凝固する際正確 にできた。眼の保護のためのフィルターにより出血等の 赤色の識別が難しくなるが、レーザー作動時のみフィル

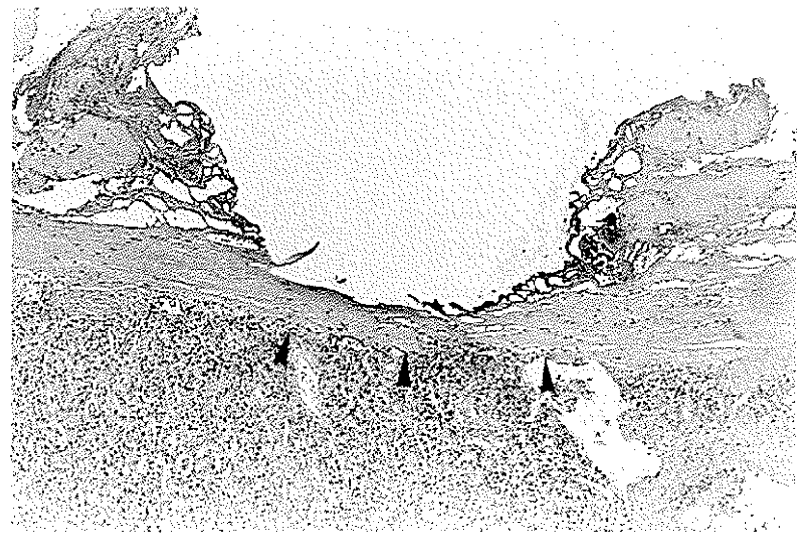

Fig.1 : Laser wound in meningioma tissue, Arrow heads indicate tumor capsule. HE stain $(x 100)$. (diameter of fiber: $0.6 \mathrm{~mm}$, laser p ower: $10 \mathrm{~W}$, distance: $1 \mathrm{~mm}$, handpiece movement: $1 \mathrm{~cm} / \mathrm{sec}$ )

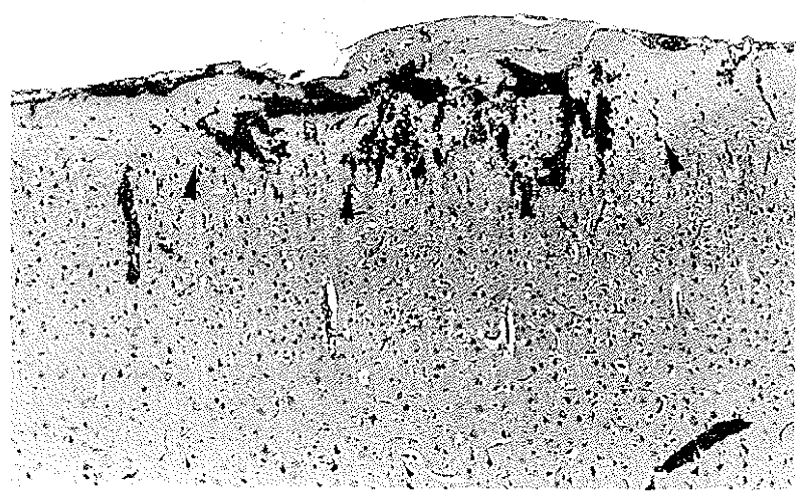

Fig.2 : Laser wound in rat cortex (arrow heads), HE stain $(x 100)$. (diameter of fiber : $0.6 \mathrm{~mm}$, laser power: $5 \mathrm{~W}$, distance: $1 \mathrm{~mm}$, handpiece movement: $1 \mathrm{~cm} / \mathrm{sec}$ )

ターが働く機構は，その久点を補っている。

〈レーザー深達度の組織学的検討〉

光ファイバーはすべて直径0.6mm使用した。髄膜腫 に対しては10Wで $1 \mathrm{~mm}$ 離して1秒照射すると，深さ1.2 $\mathrm{mm}$ まで腫演細胞核の变性, 細胞質の染色性低下, 組織構 築の破壞，腫湯内出血が羿められた。3 mm睢して9秒照 射すると，深さ $3.5 \mathrm{~mm}$ あ゙同様の所見がみられ，12秒照 射すると熱変性の及ぶ哚さは变わらなかったが組織破壊 はより顕著であった。また $1 \mathrm{~mm}$ 雖して $1 \mathrm{~cm} /$ 秒で移動照 射すると、深さ0.5m溝が形成されたが, 熱变性は腫 湯被膜内に限局して执り，腫演実質には及んでいなかっ た(Fig. 1)。星細胞腫に対しては 5 Wで $1 \mathrm{~mm}$ の距雖から 照射したが，表面より1.0mmの深さまで，核は変性し， 腫滨基質の染色性が変化していた。またラット大脳表面 から $1 \mathrm{~mm}$ 離して $1 \mathrm{~cm} /$ 秒で移動しながらレーザー照射す ると皮筫内に出血がおこり(Fig. 2), 出力 5 Wだ上 0.8 
mmの深さまで, 10Wだと1.7mmの深さまで神経細胞、グリ ア細胞の変性がみられ，組織構築の破壊がおこっていた。

\section{【考 察】}

これまでにC O $\mathrm{O}_{2} レ ー サ ゙ ー ， \mathrm{Nd} ： \mathrm{YAGレーザー,ア}$ ルゴンレーザー等が脳神経外科領域に導入され, 摘出困 難な部位の腫㾤性病变をより正確に摘出することを目的 として改良が加えられてきた。レーザーによる腫瘍切除 の特徵は，より狭い視野からアプローチできることで, 脳べラ等による脳への損傷を減らすことができる゙ら。 また腫湟摘出時の出血は従来の摘出法に比べ一般に少な くできると考えられる。今回KTPレーザーを使用して みて，その波長がもたらす高い切䦕，止血能および照射 部位に比較的限局された組織变化などのKTPレーザー 本来の特質のみならず，ガイド光が可視である，ハンド ピースが軽い等の手術機器としての使いやすさにより, 從来到達困難とされてきた深部腫癔性病変の手術にきわ めて有用であった。しかし他のレーザー手術機器と同様, 表在性病変やAVMなど血管性病变に対する有用性は他 の方法と比較してとりわけ俒れているとは考えられな かった。

今回KTPレーザー照射部位の病理変化を観察し，組 織深達度を検討したこころ, 当然照射時間, 出力によっ て組織深達度は変わるが，蒸散を目的とした使用であれ ば脳組織でも $3 \mathrm{~mm}$ 以下と考えられ，熱变性は照射部位に 比較的限局していた。またこの結果はラット肝に対する レーザー照射データとほぼ一致し13)，犬の大脳に対す る照射データともほぼ一致していだ”。

様々なレーザーの神経組織深達度については充分には 明らかにされていない。血液中のレーザ一透過度は $\mathrm{CO}_{2}$ レーザーで0.02的，KTPレーザーで0.05m. アルゴン レーザーで0.2m, Nd: YAGレーザーで $7.6 \mathrm{~mm}$ といわ れるふ。神経組織内の深達度は $\mathrm{CO}$. レーザーでは0.2 mm, アルゴンレーザーでは0. $5 \mathrm{~mm}$ 以下. $\mathrm{Nd}$ : Y AGレー ザーでは約 $3.5 \mathrm{~m}$ と報告されている゙”。TPレーザーは アルゴンレーザーに波長が一番近いので, 組織深達度も 近いと報告するものもある2!。しかし出力が同じであれ

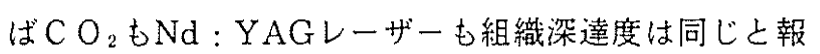
告している著者もある(6)。またNd：YAGレーザーは 传れた止血能を持つが，思いがけず深い部位の脳を損偪 してしまう（popcorn effect）ことがあることが報告さ れている13、18)。この報告では出力は20Wで使用してい るが, 今回我々はKTPレーザーを通常 $5 \mathrm{~W}$, 高くても15 Wで使用した。それゆえこの程度の出力ではその恐れは 少ないよ考えられる。またKTPレーザーの波長はへモ
グロビンの吸収極大 $(575,540,415 \mathrm{~nm})$ のうち540nm とほぼ一致するため, Nd：YAGレーザーと比べると 散乱が少ないと考えられるう。よってKTPレーザーは 照射部位に限局された熱変性を特徵とし，照射部深部ま での組織凝固能上りはむしろ蒸散能に優れているように 思われる。レーザーの出力，照射面までの距離，標的組 織の色調, 血流動態を考慮しないと一概に組織深達度を 論じることはできないが,これらの特質はKTPレーザー を顕微鏡下手術に用いる上で極めて有用と考元られる。 今回光ファイバーは直径 $0.6 \mathrm{~mm}$ のを使用したが, 耳小 骨など超微小な部位の手術には0. $3 \mathrm{~mm}$ のファイバーが適 している。しかし一般の脳神経外科領域での蒸散，凝固 を目的とした使用には $0.6 \mathrm{~mm}$ のァイバーのみで組織か らの距離を調節する事で十分である。

我々のデータが示すようにKTPレーザー照射による 熱变性は照射部位に比較的限局している。従来のレー ザーでも同様の問題点であったように，大きな腫瘳を迅 速に蒸散するには不向きであるが，ゆっくりと安全に， 出血量を少なく摘出する際にはKTPレーザーは適して いる。

このKTPレーザーと競台しうるのは超音波破砕吸引 器である。腫浣を切除していく速度では超音波破砕吸引 器に冓配が上がり，特に軟らかい腫㹸においてはその威 力は大きい。しかし超音波破砕吸引器はハンドピースが 大きく，狭い部位には挿入できないこともままあり，深 部病变での操作ではKTPレーザーの方が優れているよ うに思われた。

将来的には一般開頭手術だけではなく，内視鏡手術へ の応用も考えられる。こうした場合もKTPレーザーの 特筫は有利に動くもの上考えられる。

\section{【結論】}

KTPレーザー手術装珇は，徒来のレーザーの長所孛 継承し，かつ手術操作性に優れており，正確に狭い範国 を無血的に蒸散，切開するために優れた性能を有する。 これらは特に顕微鏡下手術に有利な特筫上考えら扎た。

\section{REFERENCES}

1) Rosomoff HL, Carroll F: Reaction of neoplasm and brain to laser. Arch Neurol 14:143-148, 1966.

2) Svaasand LO, Doiron DR, Profio AE: Light distribution in tissue during photoradiation therapy. in Workshop on Porphyrin Sensitization. Washington DC, September, 1981, New York, 
Plenum Press, 1982.

3) Ascher PW: The use of $\mathrm{CO}_{2}$ in neurosurgery. $\mathrm{i}$ n Kaplan I (ed): Laser surgery II. Jerusalem Academic Press, Jerusalem, 1978, pp. 28-30.

4) Ascher PW: Neurosurgery. in Andrews AH Jr, Polany TG (eds) :Microscopic and Endoscopic Surgery with the $\mathrm{CO}_{2}$ laser. John Wright PSG, Boston, 1982, pp. 298-314.

5) 平石守, 小西敏郎, 三山健司, 平田泰ほか：KTP レーザーとその臨床応用（特に内視鏡的治療につい て）第11回日本レーザー医学会大会論文集：425-428， 1990.

6) Beck OJ: The use of the Nd:YAG and the $\mathrm{CO}_{2}$ laser in neurosurgery. Neurosurg 3:261-266, 1980

7) Caroli F: Laser therapy for the treatment of brain tumors. J Neurosurg Sciences 35:89-92, 1988.

8) 滝澤利明：Annual review神経 1989, 脳腫㢞のレ 一ザー手術 165-172，中外医学社，1989

9 ) Abernathey CD, Davis DH, Kelly PJ: Treatment of colloid cysts of the third ventricle by stereotaxic microsurgical laser craniotomy. J Neurosurg 70:525-529, 1989.

10) Bucholz RD, Pittman T:Endoscopic coagulation of the choroid plexus using the Nd:YAG Laser: Initial experience and proposal for management. Neurosurg 28:421-427, 1991.

11) Seifert V, Gaab MR: Laser assisted microsurgical extirpation of a brain stem cavernoma: Case report. Neurosurg 25:986-990. 1989.

12) Steinberg GK, Marks MP, Shuer LM, Sogg RL et al: Occult vascular malformations of the optic chiasm. Magnetic resonance imaging diagnosis and surgical laser resection. Neurosurg 27:466-470, 1990.

13）ナイームSA，小西敏郎，大友裕美子。伊藤徹はか： ラット肝に扒けるKTP, Nd：YAGレーザーの照射 効果 第12回日本レーザ一医学会大会論文集 : 130133, 1991 .

14) Gamache FW Jr, Morgello S: The histopathological effects of the $\mathrm{CO}_{2}$ versus the KTP laser on the brain and spinal cord: A canine model. Neurosurg 32:100-104, 1993.

15) Gammache FW Jr, Patterson RH Jr: The use of the Potassium titanyl phosphate (KTP) laser in neurosurgery. Neurosurg 26:1010-1014, 1990.

16) Edwards MS, Boggan JE, Fuller TA:Review article: The laser in neurological surgery. $J$ Neurosurg 59:555-566, 1983.

17) Jain KK: Complications of use of the neodymium: yttrium-aluminum-ganet laser in neurosurgery. Neurosurg 16:759-762, 1985.

18) Wirth FP, Downing EF, Cannon CL Jr, Baker RP: Experience with the neodymium:Yttriumaluminum-Garnet laser in forty-two cases. Neurosurg 21:867-871, 1987. 